\title{
The Role of NGOs Activities with forest conservation for sustainable development: Experiences from Bangladesh
}

\author{
S. Roy ${ }^{*}$ K.K. Islam, M.A. Wadud , G.M.M. Rahman \\ Department of Agroforestry, Bangladesh Agricultural University, Mymensingh-2202 \\ Email: santanu.caritasbd@gmail.com
}

Received: $20.09 .2020 \quad$ • Accepted/Published Online: 10.11.2020 • $\quad$ Final Version: 17.12.2020

\begin{abstract}
:
The study assessed the capability of NGOs ongoing programs towards species richness and biodiversity conservation in a sustainable way of rural households in Chattogram and Moulavibazar during 2014 to 2019. Data were collected from 330 IGA participating forestdependent farmers, who were the member of different NGOs. The assessment was done using multistage random sampling. A total of 131 plant species were identified adjacent twenty villages of evergreen and semi-evergreen forest, Sal forest and Mangrove forest areas of which 43 species were fruit-producing, 41 timber species, 29 fuel wood and ornamental species, 18 medicinal and species of spices. Most of the farmers (33\%) preferred to plant fruit tree species for future plantation followed by timber species (31\%). Diversity and abundance of fruit species were found higher in all homesteads. Seven livestock, seven poultry, and two pet animal species were recorded. A total of 46 species of cultured fish species were recorded. Besides, analysis of existing management period indicates that farmers lack scientific information, almost every household presently follows traditional management systems. Finally, a homestead forest management plan, conservation of homestead species diversity through scientific management and obtaining training and support from government and NGOs, was found highly demandable by this study.
\end{abstract}

Keywords: Role of NGOs Activities, Forest Conservation, Sustainable Development, Bangladesh

\section{Introduction}

Bangladesh is situated at the complex interface of the Himalayan and Southeast Asian Biogeographic Regions, and historically was well endowed with very diverse complements of terrestrial and aquatic flora and fauna. The tropical forest is regarded as the richest in Plant Diversity. But Bangladesh has only 5 to 6\% forest area (Bashar, 1999). It has 15.4 million homesteads occupying 0.3 million hectares of land and is providing major requirements of food, fruit, vegetables, timber, and fuel wood (Abedin \& Quddus, 1990). Wide ranges of plant biodiversity for timber and food crops were found in the homesteads (Bashar, 1999).

${ }^{*}$ Corresponding Author : S. Roy, , Email: santanu.caritasbd@gmail.com 
The Government of Bangladesh has been implementing wider programs including Afforestation, cattle, goat, poultry rearing, fish farming, handicrafts, small and cottage industries, etc. The government has been paying much attention and channeling more money towards the community programs since the early 1980s, taken as an approach to poverty alleviation and environmental amelioration. Along with the government programs more than 100 national and international NGOs are also engaged in homestead/community forestry programs as part of their strategy for environmental development and poverty reductions.

The NGOs sector has grown to serve the rural poor, especially after the respective governments adopted the economic reform policies. Most of the NGOs have proved themselves capable of interacting with rural poor and this has been well recognized by the government. However, only some of the NGOs adopt a holistic approach to poverty alleviation programs for forest dependant people. The Caritas Bangladesh, BRAC, World Vision Bangladesh, Arannak Foundation, and Bangladesh Palli Daridro Bimochan Foundation and several other NGOs have been working with the government as a development partner in a different sector. Both GO and NGOs activities have been playing a significant role in engaging forest dependant farmers in income generation activities, which were considered to assist them in having a more significant role in the family, especially with regards to improving the livelihood and homestead/forest resource conservation.

\section{Materials and Methods}

Chattogram and Moulavibazar covered by evergreen and semi-evergreen forest area, Tangail and Sherpur covered by Sal forest area and Sathkhira covered by mangrove forest area were the locales of this study. The study was conducted among forest dependant farmers of the study area and was considered as the population of the study. Multistage purposive and random sampling procedures were followed to obtain the desired sample. Having a minimum of three years of membership in different NGOs and took facilities to implement IGAs from aforesaid organizations. A sample from 330 forest dependant farmers constituted the actual sample of the study IGAs participation out of 3,330 poor households was selected following a random sampling procedure. Data were collected through a pretested interview schedule. In addition, focus group discussion (FGD), scored causal diagrams (SCDs), key informant interview (KII), interview schedule, and direct field observation were also employed to obtain necessary information. Data were collected from forest dependant farmers, who were the member of different NGOs (Caritas Bangladesh, BRAC, World Vision Bangladesh, Arannak Foundation and Palli Daridro Bimochan Foundation) selected by multistage random sampling procedure during May 2015 to July 2017. The collected data were cross-checked finally in a group meeting at every village involving people at various levels. In the present study, homestead biodiversity was evaluated considering mainly the plants, domestic animals, and fishes. The following measures were used in determining biodiversity.

i. $\quad$ Species richness $(S)=$ The number of species within a homestead 
ii. Relative Prevalence $(\mathrm{RP})=$ Population of the species per homestead $\mathrm{X} \%$ homesteads with the species.

iii. Interspecies diversity: Simpon's Species Diversity Index (D)

$\mathrm{D}=1-\sum(\mathrm{pi})^{2}$

Where $\mathrm{Pi}$ is the proportion of total individuals in the ith species.

$\mathrm{Pi}=\mathrm{n} / \mathrm{N}, \mathrm{n}$ is the number of individuals in the $\mathrm{i}^{\text {th }}$ species and $\mathrm{N}$ is the total number of the individuals of all species in the community, $\mathrm{D}=$ Diversity index number, $\sum=$ is a summation sign, $\mathrm{S}=$ Total number of species, $\mathrm{D}$ can range from 0 to 1 .

i. Species evenness: The most frequently used measures, which covers large samples (Peet, 1974) are:

$\mathrm{E}=\mathrm{I}-\mathrm{I}_{\min } / \mathrm{I}_{\max }-\mathrm{I}_{\min }$

and

$\mathrm{E}=\mathrm{I} / \mathrm{I}_{\max }$

Where, $\mathrm{E}=$ Species Evenness Index, $\mathrm{I}=$ Diversity Index and $\mathrm{I}_{\min }=$ Lowest value of this index and $\mathrm{I}_{\max }=$ Highest values of this index for the given number of species and sample size.

\section{Results and Discussion}

The existing biodiversity in the rural homesteads of evergreen and semi-evergreen, sal forest and mangrove forest areas are described under - i) Species richness, ii) interspecies diversity and iii) Species evenness as follows:

\section{Species richness in the rural homesteads}

Almost all the homesteads of the study areas contained mixed vegetation of various annual and perennial plants including trees and shrubs. There were different types of domestic and pet animals and also fishes in the ponds. The findings of the study showed that there was a wide variety of plant and animal species in homesteads and their number varied from one homestead to another and also varied among the three study areas.

\section{Plant species richness in the homesteads}

A total of 131 plant species were identified in the three study areas. Among the 131 plant species, $33 \%$ fruit species, 31\% timber species, $22 \%$ fuelwood and ornamental plant species, and 14\% medicinal species. The highest number (110) of species were found in hill forest area and lowest (105) in the Sal forest area (Table 1). Alam and Masum (2005) identified 142 plant species in the Offshore Island of Bangladesh.

Table 1. Species Richness of Plant Groups in the Homesteads of Different Study Areas

\begin{tabular}{|l|c|c|c|c|c|}
\hline \multirow{2}{*}{ Study area } & \multicolumn{4}{|c|}{ No of species } & \multirow{2}{*}{ Total } \\
\cline { 2 - 5 } & Fruit & Timber & $\begin{array}{c}\text { Medicinal and } \\
\text { spices }\end{array}$ & $\begin{array}{c}\text { Fuelwood } \\
\text { and } \\
\text { ornamental }\end{array}$ & \\
\hline Hill forest & 42 & 31 & 16 & 21 & 110 \\
\hline Sal forest & 42 & 26 & 16 & 21 & 105 \\
\hline Mangrove & 41 & 26 & 17 & 25 & 109 \\
\hline
\end{tabular}




\begin{tabular}{|l|c|c|c|c|c|}
\hline forest & & & & & \\
\hline Average & 42 & 28 & 16 & 22 & 108 \\
\hline \multirow{2}{*}{ All } & 43 & 41 & 18 & 29 & 131 \\
& $(33)$ & $(31)$ & $(14)$ & $(22)$ & $(100)$ \\
\hline
\end{tabular}

Figure 1. in parentheses indicate percentages of each category

Fruits: Findings presented in Table 1 show that the number of fruit species was higher in the homesteads compared to other categories of plant species. Fruit species covered about $33 \%$ of the total vegetation of a rural homestead. A total of 42 fruit species was recorded in Sal forest and hill forest areas and 41 in the mangrove forest area. Bashar (1999) identified 44 fruit species while Mannan (2000) recorded 36 fruit species in the homestead of Gazipur districts.

Timber: The plant group 'timber' occupied the second position concerning the average number of species and covered $31 \%$ of the total vegetation of rural homesteads (Table 1). A total of 31 timber species was recorded in the hill forest area. The Equal number of timber species (26) was recorded both Sal and mangrove forest areas. Mannan (2000) recorded 30 timber species in the homestead of Gazipur districts.

Fuel and Ornamental plants: The plant group 'fuel and ornamental' occupied the third position concerning the average number of species and covered $22 \%$ of the total vegetation of rural homesteads (Table 1). A total of 25 fuel and ornamental plant species was recorded in the mangrove forest area while there were 21 species in the Sal forest area and 20 in the mangrove forest area. These were mainly trees and shrubs such as wider, baniyan tree, royal poinciana, night flowering jasmine, coral tree, china rose, bamboo, mangrove date palm, kankra, ipil-ipil, nipa palm, cape jasmine, cynometra, medlar, chandon, kasava, shimul, cane, debdaru, henna, portia tree, china box, parrot tree, goran, baen, camel's foot tree, payra, and rubber. Hossain et al. 2009 found that $19.77 \%$ ornamental species at the horticultural farm of BAU, Mymensingh.

Medicinal and spices: The plant group 'medicinal and spices' occupied the fourth position concerning the average number of species and covered $14 \%$ of the total vegetation of rural homesteads (Table 1). A total of 17 medicinal and spices plant species were recorded in the mangrove forest area. The Equal number of medicinal and spices (16) was recorded both Sal and hill forest areas. Hossain et al. 2009 found that $4.36 \%$ medicinal species and $0.04 \%$ spices species at the horticultural farm of BAU, Mymensingh.

\section{The richness of animal species}

Seven livestock species i.e cow, buffalo, goat, horse, sheep, rabbit, and pig were found in the homesteads of all three study areas. In the case of cattle, the exotic or crossbreed was found in many cases along with local breed. Black Bengal was the only species of goat (Table 2). Seven poultry species as chicken, duck, goose, Japanese quail, guinea fowl, turkey, and pigeon were available in the study villages (Table 2). Only two pet animals e.g. dog and cat of the local breed were found in homesteads of all study areas.

Table 2. Species Richness of different animal groups in the Homestead of Different Study Areas

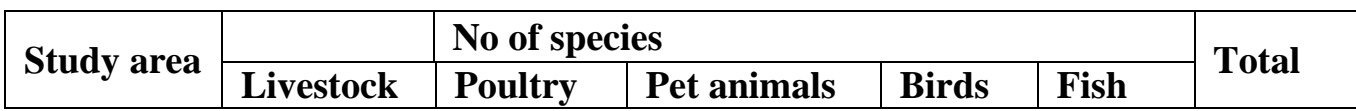




\begin{tabular}{|l|l|l|l|l|l|l|}
\hline Hill forest & 7 & 7 & 2 & 32 & 37 & 85 \\
\hline Sal forest & 7 & 7 & 2 & 32 & 40 & 88 \\
\hline $\begin{array}{l}\text { Mangrove } \\
\text { forest }\end{array}$ & 7 & 7 & 2 & 26 & 37 & 79 \\
\hline Average & 7 & 7 & 2 & 30 & 38 & 84 \\
\hline All & $\begin{array}{l}7 \\
(7)\end{array}$ & $\begin{array}{l}7 \\
(7)\end{array}$ & $\begin{array}{l}2 \\
(2)\end{array}$ & $\begin{array}{l}40 \\
(39)\end{array}$ & $\begin{array}{l}46 \\
(45)\end{array}$ & $\begin{array}{l}102 \\
(100)\end{array}$ \\
\hline
\end{tabular}

Figure 2. in parentheses indicate percentages of each category

Among the animals found in the homesteads, species richness was high in the case of fishes. A total of 40 fish species were mentioned by the respondents which they observed recently in their ponds while catching fish. The highest number (40) of species was recorded at the Sal forest area and lowest (37) at mangrove and hill forest area. In this case, respondents were asked to mention different birds as they observed in their homesteads during the last one year. The highest number (32) of species was recorded at hill and Sal forest area and lowest (26) at mangrove forest area Table 2. Islam et al. 2017 found that 2 livestock species, 3 poultry species, 2 pet animal species, 28 fish species, and 21 bird species in the homestead of Gazipur district. Alam and Masum (2005) found that poultry was the major livestock component followed by goat and cattle as occurred respectively at $63.7 \%, 11.6 \%$, and $10.6 \%$ of the households in Sandip Upazila.

\section{Relative prevalence of species}

A total of 131 plant species and 14 animal species were identified in the surveyed homesteads (Table 3). The relative prevalence of different species was determined with species found in all the three study areas. However, the relative prevalence (RP) of species of fruits, timber, medicinal, fuel and ornamental spices, and domestic animals are as follows.

Table 3. Relative Prevalence of Different Species in the Homesteads of the Study Areas

\begin{tabular}{|l|l|c|c|c|c|c|}
\hline $\begin{array}{c}\text { Common } \\
\text { Name/English } \\
\text { Name }\end{array}$ & \multicolumn{1}{|c|}{ Scientific Name } & Hill forest & $\begin{array}{c}\text { Sal } \\
\text { forest }\end{array}$ & $\begin{array}{c}\text { Mangro } \\
\text { ve forest }\end{array}$ & All & R \\
\hline Mango & Mangifera indica & 50.853 & 40.755 & 13.790 & 35.621 & 1 \\
\hline Jackfruit & Artocarpus heterophyllus & 13.571 & 37.454 & 2.480 & 17.835 & 3 \\
\hline Betelnut & Areca catechu & 19.216 & 6.620 & 2.781 & 9.540 & 8 \\
\hline Guava & Psidium guajava & 17.588 & 21.745 & 9.972 & 16.554 & 4 \\
\hline Pineapple & Ananas sativus & 8.457 & 19.456 & 1.045 & 10.037 & 7 \\
\hline Blackberry & Syzygium cumini & 2.177 & 1.429 & 1.512 & 1.716 & 19 \\
\hline Pomelo & Citrus grandis & 1.087 & 3.199 & 1.327 & 1.910 & 17 \\
\hline Lemon & Citrus aurantifolia & 13.363 & 21.248 & 5.733 & 13.086 & 6 \\
\hline Litchi & Litchi chinensis & 17.580 & 36.809 & 6.123 & 20.311 & 2 \\
\hline Papaya & Carica Papaya & 15.260 & 26.645 & 2.863 & 14.924 & 5 \\
\hline Elephant apple & Dillenia indica & 1.222 & 0.887 & 1.057 & 1.215 & 25 \\
\hline Star fruit & Averrhoa carambola & 1.774 & 0.942 & 0.119 & 0.803 & 28 \\
\hline
\end{tabular}




\begin{tabular}{|c|c|c|c|c|c|c|}
\hline Olive & Elaeocarpus robustus & 1.805 & 0.922 & 0.119 & 0.805 & 27 \\
\hline Bullocks heart & Annona reticulate & 1.428 & 0.922 & 0.132 & 0.716 & 30 \\
\hline Wood apple & Feronia limonia & 1.350 & 0.914 & 0.132 & 0.693 & 32 \\
\hline Jujubee & Zizyphus jujum & 7.340 & 6.292 & 5.041 & 6.194 & 11 \\
\hline Pome granate & Punica granatum & 2.308 & 1.375 & 1.026 & 1.599 & 21 \\
\hline Banana & Musa paradisica & 9.515 & 11.707 & 5.267 & 8.827 & 9 \\
\hline Hog plum & Spondias mombin & 3.148 & 1.043 & 3.037 & 2.421 & 16 \\
\hline Sapota & Manilkara zapota & 2.143 & 1.076 & 10.581 & 4.400 & 12 \\
\hline Tamarind & Tamarindus indica & 1.515 & 1.435 & 2.190 & 1.702 & 18 \\
\hline Palmyra palm & Borassus flabellifer & 0.782 & 0.912 & 0.826 & 0.881 & 29 \\
\hline Cucumber Tree & Averrhoa bilimbi & 1.075 & 1.554 & 1.085 & 1.238 & 24 \\
\hline Drumstick tree & Moringa oleifera & 3.675 & 1.472 & 4.254 & 3.363 & 15 \\
\hline Orange & Citrus chinensis & 10.445 & 2.168 & 0.079 & 3.184 & 13 \\
\hline Dragon & Hylocereus undatus & 0.885 & 1.110 & 0.079 & 0.610 & 35 \\
\hline Coconut & Cocos nucifera & 6.971 & 3.223 & 9.981 & 6.654 & 10 \\
\hline Monkey jack & Artocarpus lakoocha & 0.989 & 0.971 & 1.020 & 1.018 & 26 \\
\hline Sweet orange & Citrus sinensis & 1.539 & 2.628 & 0.064 & 1.102 & 22 \\
\hline Date-pump & Phoenix sylvestris & 2.174 & 1.360 & 7.363 & 3.491 & 14 \\
\hline Indian almond & Terminalia catappa & 0.817 & 0.904 & 2.087 & 1.628 & 23 \\
\hline Stone apple & Aegle marmelos & 0.824 & 0.913 & 0.174 & 0.580 & 41 \\
\hline Star gooseberry & Phyllanthus acidus & 0.824 & 0.929 & 0.174 & 0.584 & 39 \\
\hline Wax jambu & Syzygium samarangense & 1.073 & 1.988 & 1.771 & 1.922 & 20 \\
\hline Cowa & Garcinia cowa & 0.676 & 0.669 & 0.684 & 0.676 & 36 \\
\hline Custard apple & Annona squamosa & 0.647 & 0.640 & 0.625 & 0.637 & 40 \\
\hline Fig & Ficus carica & 0.753 & 0.754 & 0.745 & 0.748 & 33 \\
\hline Velvety apple & Diospyros discolor & 0.661 & 0.654 & 0.654 & 0.657 & 38 \\
\hline Rose apple & Syzygium jambos & 0.676 & 0.669 & 0.684 & 0.676 & 37 \\
\hline Bengal currant & Carissa carandas & 0.818 & 0.810 & 0.810 & 0.812 & 31 \\
\hline River ebony & Diospyros peregrine & 1.138 & 0.924 & 0.174 & 0.669 & 34 \\
\hline \multicolumn{7}{|c|}{ Timber species } \\
\hline Mahogany & Swietenia macrophylla & 59.418 & 38.281 & 15.790 & 37.830 & 1 \\
\hline Auri & Acacia auriculiformis & 11.954 & 29.354 & 6.265 & 15.688 & 5 \\
\hline Crow bean tree & Samanea saman & 10.654 & 19.827 & 9.445 & 13.329 & 2 \\
\hline Eucalyptus & Eucalyptus camaldulensis & 5.224 & 8.115 & 3.583 & 5.716 & 4 \\
\hline Indian lilac & Melia azedarach & 6.637 & 12.444 & 1.513 & 6.070 & 8 \\
\hline Sissoo & Dalbergia sissoo & 2.697 & 3.425 & 2.569 & 3.101 & 12 \\
\hline Lebbek tree & Albizia lebbeck & 3.113 & 3.161 & 2.815 & 3.131 & 6 \\
\hline Mangium & Acacia mangium & 5.388 & 7.592 & 1.615 & 4.505 & 10 \\
\hline $\begin{array}{l}\text { African } \\
\text { Mahogany }\end{array}$ & Khya senegalensis & 3.824 & 6.414 & 3.037 & 4.482 & 7 \\
\hline Beechwood & Gmelina arborea & 0.949 & 6.194 & 0.888 & 2.508 & 16 \\
\hline White sirs & Albizia procera & 6.471 & 2.814 & 3.962 & 4.373 & 11 \\
\hline Chapalish & Artocarpus chapalasha & 0.893 & 1.490 & 1.472 & 1.279 & 9 \\
\hline Golden rain tree & Cassia fistula & 1.000 & 1.218 & 0.843 & 1.016 & 14 \\
\hline Pride of India & Lagerstroemia speciosa & 1.000 & 1.245 & 1.036 & 1.445 & 3 \\
\hline Hatiamiuki & Albizia richardiana & 1.018 & 3.209 & 6.736 & 3.654 & 13 \\
\hline Kadam & Anchocephalus cadambu & 1.000 & 1.000 & 0.338 & 0.740 & 15 \\
\hline Kassod tree & Cassia siamea & 1.000 & 1.000 & 1.427 & 1.142 & 17 \\
\hline Coast sheoak & Casuarina equisetifolia & 0.002 & 1.090 & 1.000 & 0.489 & 18 \\
\hline \multicolumn{7}{|c|}{ Medicinal and Spices plants } \\
\hline Crown flower & Calotropics gigantean & 1.235 & 0.870 & 9.290 & 3.629 & 5 \\
\hline Indian gooseberry & Phyllanthus emblica & 3.345 & 1.513 & 5.390 & 3.410 & 6 \\
\hline
\end{tabular}




\begin{tabular}{|c|c|c|c|c|c|c|}
\hline Ashoka & Sara assoca & 1.000 & 1.100 & 1.163 & 1.087 & 12 \\
\hline $\begin{array}{l}\text { Beleric } \\
\text { myrobalam }\end{array}$ & Terminalia bellirica & 1.317 & 1.045 & 2.254 & 1.526 & 10 \\
\hline Basak & Adhatoda vasica & 1.000 & 13.927 & 2.245 & 5.724 & 2 \\
\hline Arjuna & Terminalia arjuna & 0.902 & 2.053 & 2.863 & 1.897 & 8 \\
\hline Black myrobalam & Terminalia chebula & 1.612 & 2.490 & 7.990 & 4.024 & 4 \\
\hline Neem & Azardirachita indica & 4.109 & 9.918 & 8.636 & 7.554 & 1 \\
\hline Basil & Ocimum basilicum & 1.063 & 11.409 & 3.236 & 5.236 & 3 \\
\hline Angel's trumpet & Datura innoxia & 1.036 & 1.018 & 1.018 & 1.024 & 14 \\
\hline Black nightshade & Solanum nigram & 1.000 & 0.963 & 1.000 & 0.987 & 15 \\
\hline Devil tree & Alstonia scholaris & 1.847 & 3.855 & 0.287 & 1.779 & 9 \\
\hline Bay leaf & Cinnamum tamala & 1.198 & 2.189 & 3.281 & 2.219 & 7 \\
\hline Cinnamon & Cinnamomum zeylanicum & 1.162 & 1.249 & 1.327 & 1.246 & 11 \\
\hline Tooth brush tree & Streblus asper & 1.036 & 1.027 & 1.027 & 1.030 & 13 \\
\hline \multicolumn{7}{|c|}{ Fuel and ornamental Plants } \\
\hline Wdier & Lannea coromandelica & 15.172 & 11.133 & 12.790 & 13.014 & 2 \\
\hline Baniyan tree & Ficus bengalensis & 0.882 & 1.726 & 0.349 & 0.926 & 12 \\
\hline Royal poinciana & Delonix regia & 1.327 & 3.254 & 1.309 & 1.011 & 11 \\
\hline $\begin{array}{l}\text { Night-flowering } \\
\text { Jasmine }\end{array}$ & Nyctanthes arbortristis & 3.727 & 2.154 & 2.318 & 2.733 & 8 \\
\hline Coral tree & Erythrina variegate & 0.963 & 16.763 & 8.218 & 8.602 & 3 \\
\hline China rose & Hibiscus rosa-sinensis & 6.309 & 8.245 & 6.318 & 6.957 & 4 \\
\hline Bamboo & Bambusa vulgaris & 15.095 & 19.356 & 16.281 & 16.934 & 1 \\
\hline Ipil-ipil & Leucaena leucocephala & 2.478 & 8.372 & 3.427 & 4.662 & 5 \\
\hline Cape jasmine & Gardenia jasminoides & 4.172 & 6.754 & 2.963 & 4.630 & 6 \\
\hline Medlar & Mimusops elengi & 3.390 & 4.245 & 1.990 & 3.209 & 7 \\
\hline Wavy-leaved fig & Ficus infectoria & 0.069 & 1.000 & 0.053 & 0.265 & 17 \\
\hline Silk cotton & Gossypium herbaceum & 2.312 & 1.923 & 1.372 & 1.884 & 10 \\
\hline False ashoka & Polyalthia longifolia & 0.704 & 0.877 & 0.010 & 0.391 & 16 \\
\hline Henna & Lawsonia inermis & 1.644 & 1.247 & 0.010 & 0.704 & 14 \\
\hline Chinese box & Murrya exotica & 3.145 & 1.436 & 1.854 & 2.145 & 9 \\
\hline Parrot tree & Butea monosperma & 0.145 & 1.190 & 1.000 & 0.680 & 15 \\
\hline Camel's foot tree & Bauhinia variegate & 0.620 & 1.775 & 0.384 & 0.842 & 13 \\
\hline \multicolumn{7}{|c|}{ Domestic birds } \\
\hline Chicken & Gallus gallusdomesticus & 11.018 & 8.081 & 6.763 & 8.621 & 1 \\
\hline Duck & Antidae anseriformes & 7.500 & 5.063 & 7.009 & 6.524 & 2 \\
\hline Pegion & Colamba livia & 1.728 & 1.543 & 4.198 & 2.405 & 4 \\
\hline Japanese quail & Coturnix japonica & 3.393 & 4.123 & 5.251 & 4.240 & 3 \\
\hline Guinea fowl & Numida meleagris & 0.919 & 0.714 & 0.877 & 0.834 & 6 \\
\hline Goose & Anser cygnoides & 0.575 & 0.568 & 0.561 & 0.568 & 7 \\
\hline Turkey & Meleagris gallopavo & 0.876 & 0.893 & 0.876 & 0.882 & 5 \\
\hline \multicolumn{7}{|c|}{ Domestic animals } \\
\hline Buffalo & Bubalus bubalis & 1.084 & 1.036 & 1.399 & 1.178 & 5 \\
\hline Cow & Bos Taurus & 4.954 & 7.163 & 5.409 & 5.842 & 1 \\
\hline Hare & Lepus spp & 2.286 & 2.125 & 3.264 & 2.579 & 4 \\
\hline Horse & Equus feruscaballus & 0.317 & 0.336 & 0.250 & 0.300 & 7 \\
\hline Goat & Capra aegagrushircus & 5.296 & 6.227 & 5.176 & 5.564 & 2 \\
\hline Sheep & Ovie saries & 2.475 & 2.447 & 5.774 & 3.477 & 3 \\
\hline Swine & Sus scrofa & 0.156 & 3.990 & 0.135 & 0.877 & 6 \\
\hline
\end{tabular}

Fruits: In the hill forest area, Mango (50.853), betel nut (19.216), guava (17.588), litchi (17.580) and papaya (15.260) were five most prevalent fruit species followed by jackfruit 
(13.571), lemon (13.363), orange (10.445), banana (9.515) and pineapple (8.457). The prevalence of mango (40.755), jackfruit (37.454), litchi (36.809), papaya (26.645), guava (21.745), lemon (21.248), pineapple (19.456), banana (11.707), lotkon/Burmese grape (7.446) and betel nut (6.620) was higher in Sal forest area; while mango (13.790), sapota (10.581), coconut (9.981), guava (9.972), date plum (7.363), litchi (6.123), lemon (5.733) banana (5.267), jujube (5.041) and drumstick (4.254) had a higher prevalence in the mangrove forest area. All forest Mango, litchi, jackfruit, guava, papaya were the five most prevalent fruit species in the study areas (Table-3).

Timber: Regarding the timber species, the most prevalent species in hill forest area was mahogony (59.418) followed by akashmoni (11.954), rain tree (10.654), goraneem (6.637); white siris (6.471), mangium (5.388), eucalyptus (5.224) and lombu (3.824). Mahogony (38.281) was the most prevalent species and ranked 1st in Sal forest homestead areas and other species were akashmoni (29.354), rain tree (19.827), goraneem (12.444); eucalyptus (8.115); mangium (7.592), lombu (6.414) Beachwood (6.194); Sal (5.816) and pitraj (4.980). Mahogany ranked 1st in the Mangrove forest. Among other species, rain tree, rajkoroi, akashmoni, sheel koroi, eucalyptus, lombu, lebbek tree, sissoo, and mangium were more prevalent in mangrove forest homestead areas. According to the mean dominance rank of all forest, prevalence of, mahagony, raintree, jarul, eucalyptus, akashmoni were relatively higher in the study area (Table-3).

Medicinal and spices: Regarding the medicinal and species were recorded at three study areas, neem was the most prevalent species followed by basak, basil, black myrobalam, crown flower, Indian gooseberry and bay leaf (Table-3).

Fuel and ornamental: Based on mean dominance bamboo occupied the 1st position followed by wider/jiga, coral tree/maunder, china rose, ipil-ipil, cape jasmine, medlar, night flowering jasmine were relatively higher in the study area (Table-3).

Domestic birds and animals: the chicken was the most prevalent followed by duck, cow, goat, koel, sheep, rabbit, and buffalo at each of the three study areas. The RP value for swine, turkey, titir, goose, and the horse was very low in all the study areas indicating a low prevalence of these species (Table-3).

\section{Interspecies diversity in the rural homesteads}

The species diversity index was computed the following Simpson's Species Diversity Index (D). Results presented in Table 4.1 and Table 4.2 showed that species diversity varied with different farm categories and also among the study areas. The species diversity index values $0.787585657,0.738947499$, and 0.649296817, respectively for marginal, small, and medium farms indicate that plant biodiversity was higher in all categories of the farm (Table 4.1).

Table 4. Species Diversity Indices of Different Categories of Species in Different Forest Zones of the Studied Areas of Bangladesh

\begin{tabular}{|c|c|c|c|}
\hline Farm Category & $\begin{array}{c}\text { Plant and animal } \\
\text { group }\end{array}$ & $\begin{array}{c}\text { Relative } \\
\text { abundance }\left(\mathbf{P i}^{2}\right)\end{array}$ & $\begin{array}{c}\text { Diversity index } \\
\text { (D) }\end{array}$ \\
\hline
\end{tabular}




\begin{tabular}{|c|c|c|c|}
\hline Farm Category & $\begin{array}{c}\begin{array}{c}\text { Plant and animal } \\
\text { group }\end{array} \\
\end{array}$ & $\begin{array}{c}\text { Relative } \\
\text { abundance }\left(\mathbf{P i}^{2}\right)\end{array}$ & $\begin{array}{c}\text { Diversity index } \\
\text { (D) }\end{array}$ \\
\hline \multirow{7}{*}{$\begin{array}{l}\text { Marginal (>0.20 } \\
\text { ha area) }\end{array}$} & Fruit & 0.045968778 & 0.954031222 \\
\hline & Timber & 0.076556284 & 0.923443716 \\
\hline & Medicinal and spices & 0.095249903 & 0.904750097 \\
\hline & Fuel and ornamental & 0.109147867 & 0.890852133 \\
\hline & Homestead birds & 0.21332129 & 0.78667871 \\
\hline & Homestead animals & 0.201735182 & 0.798264818 \\
\hline & All & 0.212414343 & 0.787585657 \\
\hline \multirow{7}{*}{$\begin{array}{l}\text { Small } \\
(0.21-1.00 \text { ha } \\
\text { area })\end{array}$} & Fruit & 0.07722794 & 0.92277206 \\
\hline & Timber & 0.153340369 & 0.846659631 \\
\hline & Medicinal and spices & 0.116433071 & 0.883566929 \\
\hline & Fuel and ornamental & 0.100583696 & 0.899416304 \\
\hline & Homestead birds & 0.233159894 & 0.766840106 \\
\hline & Homestead animals & 0.184446979 & 0.815553021 \\
\hline & All & 0.261052501 & 0.738947499 \\
\hline \multirow{7}{*}{$\begin{array}{l}\text { Medium } \\
\text { (1.1-3 ha area) }\end{array}$} & Fruit & 0.084997001 & 0.915002999 \\
\hline & Timber & 0.119639121 & 0.880360879 \\
\hline & Medicinal and spices & 0.108710185 & 0.891289815 \\
\hline & Fuel and ornamental & 0.13555251 & 0.86444749 \\
\hline & Homestead birds & 0.258947061 & 0.741052939 \\
\hline & Homestead animals & 0.193844206 & 0.806155794 \\
\hline & All & 0.350703183 & 0.649296817 \\
\hline
\end{tabular}

Forest area-wise analysis of species diversity presented in Table 4.2 showed that the diversity of plant species was higher in each of the forest areas. The diversity index (D) values against each of the plant groups and the overall plant biodiversity index (0.7216361) indicates that plant biodiversity was higher in the areas, while the evenness index (E) value of 0.598736641 indicates that the abundance of different plant species was somewhat dissimilar i.e. proportion of all the species were not similar over the area.

Considering all the three study areas together, diversity was the highest with fruits (0.93166513) followed in descending order by medicinal and spices (0.9085095), fuel, and ornamental plants $(0.887265707)$ timber $(0.885586674)$, homestead animals $(0.8091042)$ and homestead birds $(0.77344853)$. The total evenness values against the three study areas (0.756123336, 0.638992843 and 0.57443528 in Mangrove forest, Hill forest, and Sal forest respectively) indicate that the abundance of different species was very dissimilar.

Table 5. Species Diversity of Different Plant Groups and Animals in Rural Homesteads

\begin{tabular}{|c|c|c|c|c|c|}
\hline $\begin{array}{l}\text { Study } \\
\text { areas }\end{array}$ & $\begin{array}{l}\text { Plant and } \\
\text { animal group }\end{array}$ & $\begin{array}{l}\text { Relative } \\
\text { abundance } \\
\left(\mathbf{P i}^{2)}\right.\end{array}$ & $\begin{array}{l}\text { Diversity } \\
\text { index (D) }\end{array}$ & Evenness (E) & t-value \\
\hline \multirow[t]{5}{*}{ Hill forest } & Fruit & 0.079375323 & 0.9206246 & 0.299961284 & \multirow{5}{*}{$\begin{array}{c}\mathrm{M}-\mathrm{H} \\
=.754 \\
\mathrm{M}-\mathrm{S} \\
=.430 \\
\mathrm{H}-\mathrm{S}=-.373\end{array}$} \\
\hline & Timber & 0.1929974 & 0.8070026 & 0.172713898 & \\
\hline & $\begin{array}{l}\text { Medicinal and } \\
\text { spices }\end{array}$ & 0.083891884 & 0.9161081 & 0.745006517 & \\
\hline & $\begin{array}{l}\text { Fuel and } \\
\text { ornamental }\end{array}$ & 0.138271685 & 0.8617283 & 0.361606934 & \\
\hline & Homestead birds & 0.25890737 & 0.7410926 & 0.55176932 & \\
\hline
\end{tabular}




\begin{tabular}{|c|c|c|c|c|}
\hline & $\begin{array}{l}\text { Homestead } \\
\text { animals }\end{array}$ & 0.202794432 & 0.7972055 & 0.704443122 \\
\hline & Total & 0.260827126 & 0.739172874 & 0.638992843 \\
\hline \multirow[t]{7}{*}{ Sal forest } & Fruit & 0.084948314 & 0.915051686 & 0.280282478 \\
\hline & Timber & 0.099335294 & 0.900664706 & 0.387189052 \\
\hline & $\begin{array}{l}\text { Medicinal and } \\
\text { spices }\end{array}$ & 0.146506465 & 0.853493535 & 0.426602334 \\
\hline & $\begin{array}{l}\text { Fuel and } \\
\text { ornamental }\end{array}$ & 0.108545863 & 0.891454137 & 0.438699793 \\
\hline & Homestead birds & 0.23266248 & 0.76733752 & 0.61401022 \\
\hline & $\begin{array}{l}\text { Homestead } \\
\text { animals }\end{array}$ & 0.194005555 & 0.805994445 & 0.73635594 \\
\hline & Total & 0.290140026 & 0.709859974 & 0.57443528 \\
\hline \multirow{7}{*}{$\begin{array}{l}\text { Mangrove } \\
\text { forest }\end{array}$} & Fruit & 0.052259515 & 0.947740485 & 0.466713933 \\
\hline & Timber & 0.082159737 & 0.917840263 & 0.468131228 \\
\hline & $\begin{array}{l}\text { Medicinal and } \\
\text { spices }\end{array}$ & 0.106258425 & 0.893741575 & 0.553589322 \\
\hline & $\begin{array}{l}\text { Fuel and } \\
\text { ornamental }\end{array}$ & 0.119719879 & 0.880280121 & 0.334113267 \\
\hline & Homestead birds & 0.20947398 & 0.79052602 & 0.68198036 \\
\hline & $\begin{array}{l}\text { Homestead } \\
\text { animals }\end{array}$ & 0.206008216 & 0.793991784 & 0.693453618 \\
\hline & Total & 0.220422593 & 0.779577407 & 0.756123336 \\
\hline \multirow[t]{7}{*}{ Overall } & Fruit & 0.06833487 & 0.93166513 & 0.34032133 \\
\hline & Timber & 0.114413326 & 0.885586674 & 0.213176601 \\
\hline & $\begin{array}{l}\text { Medicinal and } \\
\text { spices }\end{array}$ & 0.0914905 & 0.9085095 & 0.0050828 \\
\hline & $\begin{array}{l}\text { Fuel and } \\
\text { ornamental }\end{array}$ & 0.112734293 & 0.887265707 & 0.30587639 \\
\hline & Homestead birds & 0.22655147 & 0.77344853 & 0.63057256 \\
\hline & $\begin{array}{l}\text { Homestead } \\
\text { animals }\end{array}$ & 0.1908958 & 0.8091042 & 0.74835141 \\
\hline & Total & 0.2783639 & 0.7216361 & 0.598736641 \\
\hline
\end{tabular}

Total plant biodiversity was higher in Mangrove forest areas with an index value of 0.779577407 which gradually decreased in Hill forest and Sal forest as shown in Table 4.2. The diversity index value against each plant and animal group in the Mangrove forest was higher than in the other two areas. The t-test indicated that there was a significant difference among Mangrove, Hill, and Sal forest with respect to the diversity of different plant and animal groups ( $\mathrm{M}-\mathrm{H} \mathrm{t}=0.754),(\mathrm{M}-\mathrm{S} \mathrm{t}=-.430)$ and $(\mathrm{H}-\mathrm{S} \mathrm{t}=-.373)$. However, considering the frequency of occurrence, the relative prevalence of different species, and the diversity index (D), it can be said that plant biodiversity is increasing significantly with increase NGOs activities as well as through massive plantations.

\section{Conclusion:}

The identification of the most prevalent and dominant fruit, timber, medicinal and other species is an important finding of the study. In this study, it is observed that the homestead plant composition, diversity, and species richness were medium level in the study areas. Therefore, there was a lack of scientific knowledge of the farmers, an absence of proper 
planning, and no specific goals. A comprehensive agroforestry planning, proper scientific management of plants using agroforestry cultivars are needed to promote plant and animal diversity. Government and NGOs should initiative a program for the conservation of forests at local levels.

\section{References}

[1] Abedin MZ, Quddus MA .1990. Household fuel situation, Homegarden and agroforestry practice at six ageo-ecologically different locations of Bangladesh. In: Abedin, MZ, Lai CK, Ali MO (Eds), Homestead plantation and Agroforestry in Bangladesh, pp19-34, BARI, Joydebpur, Bangladesh.

[2] Abedin, M. Z., \& Quddus, M. A. (1988). Household fuel situation, home gardens and agroforestry practices at six agro-ecologically different locations of Bangladesh. In National Workshop on Homestead Plantations and Agroforestry in Bangladesh, Joydebpur (Bangladesh), 17-19 Jul 1988.

[3] Alam, M. S., Masum, K. M., Campus, B. F. R. I., \& Sholashahor, B. (2005). Status of homestead biodiversity in the offshore island of Bangladesh. Research Journal of Agriculture and Biological Sciences, 1(3), 246-253.

[4] Atikullah SM, Hossain ABME, Miah GU, Rahmn MO.2016. Homestead plant diversity in the southcentral coastal saline region of Bangladesh: utilization and conservation. International Journal of Emerging Trends in Science and Technology 3(5) 4029-4041.

[5] Basher MA. 1999. Homegarden Agroforestry: Impact on Biodiversity conservation and household food security (A case study of Gazipur district, Bangladesh), MSc thesis, Agriculcural University of Norway, Olso, Norway.

[6] Hossain A, Chowdhury MAS, Islam MSTT, Malaker PK and Iqbal SM. 2009. Plant Diversity of the Horticultural Farm of Bangladesh Agrucultural University. Bangladesh Journal of Agricultural Research 34(2) 189-204.

[7] Islam MR, Baten MA, Hossain SMA, Afrose SM and Naher K. 2017. Changes in Homestead Biodiversity with Modernization in the Rural Areas of Bangladesh. International Journal of Agricultural Research, Innovation and Technology 7(1): 32-37.

[8] Mannan A. 2000. Plant biodiversity in the homesteads of Bangladesh and its utilization in crop improvement, Ph. D. thesis. Department of Genetics and Plant Breeding. Bangabandhu Sheikh Mujibur Rahman Agricultural University, Salna, Gazipur Bangladesh.

[9] Peet RK. 1974. The measurements of species diversity. Ann. Rev. Eeal. System. 5 285-307. 